\title{
The Effect of Corporate Taxpayer Compliance, the Increase of Corporate Taxpayers' Number and Tax Audits on Income Tax Receipts of Article 25 with Taxation Sanctions as a Moderating Variable in KPP Pratama Medan Petisah
}

\author{
Retnawati Siregar ${ }^{1}$, Ilham Ramadhan Nasution', Muhammad Adil Arifin ${ }^{3}$ \\ ${ }^{1,2,3}$ Accounting Study Program, Faculty of Economics and Business, University of Medan Area, Indonesia \\ adilarifin@outlock.com
}

\begin{abstract}
This study aims to measure how the effect corporate taxpayer compliance, the increase of corporate taxpayers' number and tax audits on the income tax receipts of article 25 with taxation sanctions as a moderating variable. The population of this study amounted to 12,815 business entities sourced from secondary data, if by KPP Pratama Medan Petisah from 2014-2016, the sample of this study amounted to 129 business entities selected randomly, then the number of respondents in this study were 100 business entities which were then processed using multiple linear regression and Moderated Regrression Analysis (MRA). Independent and Dependent variables were measured using the Ratio Scale and Likert Scale. The results of this study indicate that the increase of corporate taxpayers' number has a significant effect on the income tax receipts of article 25 and compliance with corporate taxpayers and tax audit does not significantly affect the income tax receipts of article 25, but the existence of tax sanctions as a moderating variable significantly affect corporate taxpayer compliance, the increase of corporate taxpayers' number and tax audits on the income tax receipts of article 25. This was evidenced by the increase in Adjusted $R$ Square from $8.9 \%$ to 96.6\%. And it can be ascertained that tax sanctions moderate (increase) the effect of corporate taxpayer compliance, the increase of corporate taxpayers' number and tax audits on the income tax receipts of article 25.
\end{abstract}

Keywords: Taxpayers; increase; economy; business.

\section{Introduction}

Indonesian state imposes the income tax on the income of individuals and entities based on various provisions. Income tax that took effect on January 1, 1984 is Law No. 7 of 1983 which is based on the Pancasila philosophy and the 1945 Constitution in which there are provisions that uphold citizens' rights and place tax obligations as state obligations and are a means of active public participation in state funding and national development. With the Income Tax Constitution, the taxpayer on income is always subject to state levies in the form of tax. The rates are large according to the type of goods produced. Because income tax is a type of tax collected at the national level, so it can be categorized as a central tax group. With the issuance of this law, the government has provided many facilities for taxpayers to be given trust and freedom in calculating the tax payable on the income tax income obtained is called self-assessment.

In Indonesia itself is very dependent on the income tax in the country. Because tax revenues nearly meet state spending. Thus the tax in Indonesia is very significant, therefore the government tries to increase tax revenue every year so that it can cover up to $80 \%$ of state spending. There are many sectors in Indonesia that can contribute to state spending, but the sectors outside of tax have not been able to have a significant impact. The government sets tax revenue realization targets every year and there are many ways by the government to make taxpayers willing to pay tax payable, ranging from socialization, tax rates adjusted to 
personal income to tax penalties so that taxpayers comply with existing tax norms. This is done to make taxpayers willing to pay tax payable and meet the government's realization target each year. The impact of taxes on state spending and state development in Indonesia, if the government does not encourage its citizens to pay taxes, it can make national development constrained and unable to develop. But in practice the Customs Law still poses a dilemma for the government as the holder of taxation authority and other obstacles faced are that there are still taxpayers who do not understand the contents of the tax payment letter, even do not know clearly the filling techniques, so that there are still error in filing tax payment. But now, the mandatory attitude still has an impact on the ineffectiveness of the implementation provided by the Directorate General (Dirjen) of Taxes, the possibility of the tax payable that is reported to be incomplete and inaccurate to the detriment of the state treasury.

\section{Review of Literature}

\subsection{Tax}

According to Adriani, translated by R. Santoso Brotodiharjo in his book Waluyo (2013: 2) Taxes are dues to the State (which can be forced) that are owed by the obligation to pay them according to regulations, with no achievement, those that can be directly appointed, and the use is to finance public expenditures related to the duty of the state to administer government.

Tax is a compulsory levy paid by the people to the state and will be used for the benefit of the government and the general public. People who pay taxes will not feel the benefits of taxes directly, because the tax is used for public purposes, not for personal gain. Taxes are one source of government funds for development, both the central and regional governments. Tax collection can be forced because it is carried out according to the law

\subsection{Income Tax of Article 25}

Income Tax of article 25 is the amount of income tax installments in the current tax year that must be paid by the Individual Taxpayer or Corporate Taxpayer for each month from the January tax period to the December tax period. Income Tax Installments 25 must be paid or deposited every month no later than the 15th of the following month, if the 15th is a holiday including Saturdays or national holidays, then the payment or deposit of the tax can be made on the next working day.

\subsection{Corporate Taxpayer Compliance}

In Indonesian General Dictionary, compliance means submitting to or complying with teachings or rules. Eliyani (1989) states that taxpayer compliance is defined as entering and reporting in due time the information needed, correctly filling the amount of tax owed, and paying taxes on time without coercion.

Corporate taxpayer compliance stated by Norman D. Nowak (Zain: 2004) as quoted by Siti Kurnia Rahayu (2010: 138) explains that:

"As a climate of compliance and awareness of fulfillment of tax obligations is reflected in situations where:

1. Taxpayers understand or try to understand the provisions of tax legislation

2. Filling the tax form correctly and clearly 
3. Calculate the amount of tax owed correctly

4. Paying taxes on time.

According to Gunaidi (2013: 94) in this case it means that taxpayers have a willingness to fulfill their tax obligations in accordance with applicable regulations without the need for inspection, careful investigation, warning or threat and the application of sanctions both legal and administrative.

\subsection{The Increase of Corporate Taxpayers' Number}

According to Susanti (2014: 156) the increase's number of active taxes registered with the Tax Office with tax identification number (NPWP). So the growth in the number of corporate taxpayers is the corporate taxpayer who consciously and actively registers his business entity in carrying out its tax obligations. Taxpayers are known from the data of taxpayers who register and submit their tax returns at KPP Pratama Medan Petisah each year.

\subsection{Tax Audits}

According to the Regulation of the Minister of Finance of the Republic of Indonesia Number 17 / PMK.03 / 2013 concerning Audits Procedures, what is meant by an audits is a series of activities to collect and process data, information, and / or evidence carried out objectively and professionally based on an inspection standard to test compliance with taxation compliance and / or for other purposes in implementing the provisions of the taxation legislation.

\subsection{Taxation Sanctions}

According to Mardiasmo (2011: 59) "Tax sanctions are guarantees that the provisions of tax legislation (tax norms) will be obeyed. Or can taxpayers not violate taxation norms". Tax sanctions are a deterrent to taxpayers from violating taxation provisions

\section{Research Methods}

Population is a generalization area that consists of subjects or objects that have certain characteristics and qualities determined by a researcher to be studied and then drawn a conclusion (Sugiyono (2008: 115). The population of this study is all business entities that pay their income tax to KPP Pratama Medan Petisah in the amount of 12,815.

The sample is part of the number and characteristics possessed by the population (Sugiyono, 2014). The number of samples taken in the study was 129.15 rounded up to 129 corporate taxpayers.

Multiple linear regression analysis is actually the same as simple linear regression analysis, only the independent variables are more than one. The general equation is:

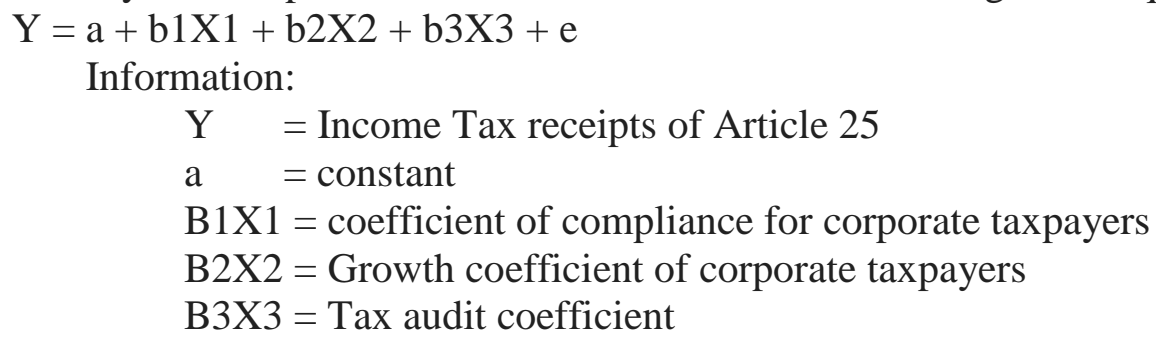


Simultaneous test is intended to find out the relationship between the independent and dependent variables by testing all the independent variables (together) with the dependent variable

The statistical test $t$ is used to find out how far the influence of one independent variable individually in explaining the variation of the dependent variable (Sugiyono, 2014; 56). T test is used to determine whether the independent variable partially has a significant effect on the dependent variable.

Correlation analysis can be continued by calculating the coefficient of determination serves to determine the percentage of the effect of variable $\mathrm{X}$ on variable Y. According to Gujarati (2012: 172) to see the effect of each independent variable on partially dependent variables

According to Ghozali (2011: 223) Interaction Test or often referred to as Moderated Regression Analysis (MRA) is a special application of linear regression where the regression equation contains interaction elements (multiplication of two or more independent variables)

$$
\begin{aligned}
& \text { Equation (1): } Y=a+b 1 X 1+b 2 X 2+b 3 X 3+b 4 z|X 1 . X 2 . X 3-Z| \\
& \text { Equation (2): } Y=a+b 1 Z X 1+b 2 Z X 2+b 3 Z X 3+b 4 A B S X 1 \_X 3
\end{aligned}
$$

\section{Discussion}

a. The Effect of Corporate Taxpayer Compliance on Income Tax Receipts of Article 25

The variable corporate taxpayer compliance partially shows that there is no significant effect on income tax of article 25, this result is seen at a significance value of 0.173 , which is greater than 0.005 . These results are in line with research conducted by Rahayu (2016) and Putra, et al (2015) which states that compliance with corporate taxpayers has no significant effect on income tax of article 25. However these results contradict the research conducted by Susanti, et al (2014) which states that corporate taxpayer compliance has a significant effect on Income Tax receipts of Article 25.

b. The Effect of the Increase in Corporate Taxpayers' Number on Income Tax Receipts of Article 25

The increase in corporate taxpayers' number in this study showed a significant effect where the value of 0.008 is lower than 0.05 . This result is contrary to previous research conducted by Putra, et al (2015) states that the increase in corporate taxpayers' number has no significant effect on the receipt of income tax of article 25.

\section{c. The Effect of Tax Audits on Income Tax Receipts of Article 25}

The tax audit variable in this study shows no significant effect where the value of 0.369 is greater than 0.05 . The results of this study are contrary to previous research conducted by Susanti, et al (2014) which states that tax audits have a significant effect on income tax of article 25 .

d. The Simultaneous Effect of Corporate Taxpayers Compliance, the Increase in Corporate Taxpayers' Number and Tax Audits on Income Tax Receipts of Article 25

Variable compliance of corporate taxpayers, the increase in corporate taxpayers' number and tax audits have a significant effect simultaneously on income tax receipts of 
article 25 . With a significance value of 0.007 which is lower than 0.05 , this is in line with research by Susanti, et al (2014), Putra, et al (2015) and Rahayu (2016).

e. Tax Sanctions can Increase (Moderate) the Corporate Taxpayers Compliance, the Increase in Corporate Taxpayers' Number and Tax Audits on Income Tax Receipts of Article 25

Table 1. Data Analysis

Information:

\begin{tabular}{|l|l|l|}
\hline Form Of Business Agency & Frequency & Percent (\%) \\
\hline Perseroan Terbatas (PT), & 38 & $38 \%$ \\
\hline Perusahaan Firma (FA), & 30 & $30 \%$ \\
\hline Perseroan Komanditer (CV) & 32 & $32 \%$ \\
\hline Total & 100 & $100 \%$ \\
\hline
\end{tabular}

From the data table above the questionnaires filled out by Limited Companies (Perseroan Terbatas (PT)) were 38 PT or 38\%, Firm Companies (Perusahaan Firma (FA)) were $30 \mathrm{FA}$ or $30 \%$ and the last was 32 limited partnership companies (Perseroan Komanditer (CV)) by $32 \%$.

\begin{tabular}{|c|c|c|c|c|c|c|}
\hline 1. & \multicolumn{6}{|c|}{ Paying tax installments owed correctly (P1) } \\
\hline \multirow[b]{2}{*}{$\begin{array}{l}\text { Respondents' } \\
\text { Answers }\end{array}$} & SS & $\mathrm{S}$ & $\mathrm{N}$ & TS & STS & Total \\
\hline & 7 & 25 & 44 & 19 & 5 & 100 \\
\hline 2. & \multicolumn{6}{|c|}{$\begin{array}{c}\text { does income tax receipts of article } 25 \text { make it easier for you to pay tax } \\
\text { installments owed (P2) }\end{array}$} \\
\hline Respondents' & SS & $\mathrm{S}$ & $\mathrm{N}$ & $\mathrm{TS}$ & STS & Total \\
\hline Answers & 4 & 32 & 59 & 5 & 0 & 100 \\
\hline
\end{tabular}

The results of the questionnaire answers obtained from 100 respondents for Variable Income Tax receipts of Article $25(\mathrm{Z})$, namely:

a. In the first question, 7 respondents who strongly agreed, 25 respondents who agreed, 44 respondents who stated neutral, 19 respondents who disagreed and 5 respondents who strongly disagreed.

b. In the second question, there were 4 respondents who strongly agreed, 32 respondents who agreed, and 59 respondents who stated neutral, and 5 respondents who disagreed.

\begin{tabular}{|c|c|c|c|c|c|c|c|}
\hline 1. & \multicolumn{6}{|c|}{ Always pay income tax receipts on time (P1) } \\
\hline $\begin{array}{c}\text { Respondents' } \\
\text { Answers }\end{array}$ & SS & S & N & TS & STS & Total \\
\hline \multirow{2}{*}{2.} & \multicolumn{5}{|c|}{ Always pay the income tax receipts deficiency before receiving a } \\
& \multicolumn{7}{|c|}{ letter of reprimand and a fine (P2) } \\
\hline $\begin{array}{c}\text { Respondents' } \\
\text { Answers }\end{array}$ & SS & S & N & TS & STS & Total \\
\cline { 2 - 7 } & 27 & 49 & 18 & 1 & 100 \\
\hline
\end{tabular}

\begin{tabular}{|c|c|c|c|c|c|c|}
\hline 3. & \multicolumn{6}{|c|}{ Always calculate tax payable properly (P3) } \\
\hline $\begin{array}{c}\text { Respondents' } \\
\text { Answers }\end{array}$ & SS & S & N & TS & STS & Total \\
\cline { 2 - 7 } & 1 & 38 & 55 & 6 & 0 & 100 \\
\hline 4. & \multicolumn{4}{|c|}{ Taxpayers know how to calculate and pay tax payable (P4) } \\
\hline
\end{tabular}




\begin{tabular}{|c|c|c|c|c|c|c|}
\hline Respondents' & SS & S & N & TS & STS & Total \\
\cline { 2 - 7 } Answers & 2 & 15 & 64 & 19 & 0 & 100 \\
\hline 5. & \multicolumn{7}{|c|}{ Report tax payable in a timely manner (P5) } \\
\hline $\begin{array}{c}\text { Respondents' } \\
\text { Answers }\end{array}$ & SS & S & N & TS & STS & Total \\
\cline { 2 - 7 } & 13 & 27 & 46 & 13 & 1 & 100 \\
\hline
\end{tabular}

a. In the first question, there were 6 respondents $(6 \%)$ who agreed, 28 respondents $(28 \%)$ who agreed, 44 respondents $(44 \%)$ stated neutral, 22 respondents $(22 \%)$ who disagreed.

b. In the second question, 5 respondents (5\%) stated that they were very ally, 27 respondents (27\%) who agreed, 49 respondents (49\%) stated neutral, 18 respondents (18\%) who disagreed and 1 respondent ( $1 \%$ ) strongly disagrees

c. In the third question, 1 respondent (1\%) stated strongly agreed, 38 respondents $(38 \%)$ stated agreed 55 respondents $(55 \%)$ stated neutral, 6 respondents $(6 \%)$ stated disagreed.

d. In the fourth question, 2 respondents $(2 \%)$ stated strongly agree, 15 respondents $(15 \%)$ stated agreed, 64 respondents $(64 \%)$ stated neutral, 19 respondents (19\%) stated disagreed.

e. On the fifth question, as many as 13 respondents (13\%) stated strongly agree, 27 respondents $(27 \%)$ stated agreed, 46 respondents $(46 \%)$ stated neutral, 13 respondents $(13 \%)$ stated disagreed. 1 respondent $(1 \%)$ expressed strongly disagree.

\begin{tabular}{|c|c|c|c|c|c|c|c|}
\hline \multirow{2}{*}{1.} & \multicolumn{6}{|c|}{ Registering yourself as a taxable entrepreneur voluntarily because of his } \\
own awareness (P1)
\end{tabular}

a. In the first question (Registering yourself as a taxable entrepreneur voluntarily because of his own awareness) as many as 4 respondents (4\%) expressed strongly agree, 16 respondents (16\%) agreed, 48 respondents $(48 \%)$ stated neutral, 21 respondents $(21 \%)$ stated disagree then 11 respondents $(11 \%)$ stated strongly disagree.

b. In the second question (Registering yourself as a taxable entrepreneur voluntarily through socialization from the tax office) as many as 2 respondents (2\%) expressed strongly agree, 
17 respondents $(17 \%)$ agreed, 58 respondents $(58 \%)$ stated neutral, 17 respondents $(17 \%)$ stated that they did not agree, then 4 respondents $(4 \%)$ stated strongly disagree.

c. In the third question (With the supervision conducted by KPP tightly it will increase the growth of the number of corporate taxpayers) as many as 8 respondents (8\%) expressed strongly agree, 30 respondents (30\%) agreed, 41 respondents (41\%) stated neutral, 17 respondents (17\%) said they disagreed and 4 respondents $(4 \%)$ stated strongly disagree.

d. In the fourth question (The low tax rates imposed makes you register your own business entity as a new taxpayer) as many as 3 respondents (3\%) strongly agree, 17 respondents (17\%) agree agree 40 respondents $(40 \%)$ state neutral, 26 respondents $(26 \%)$ stated that they did not agree, then 14 respondents (14\%) stated strongly disagree.

e. In the fifth question (Obtaining NPWP is the reason you register yourself as a condition to get a business license) as many as 14 respondents (14\%) stated strongly agree, 38 respondents $(38 \%)$ agreed, 39 respondents $(39 \%)$ stated neutral, 9 respondents (9\%) stated that they did not agree.

\begin{tabular}{|c|c|c|c|c|c|c|}
\hline \multirow{2}{*}{1} & \multicolumn{6}{|c|}{ Tax audits need to be carried out to test compliance with taxation } \\
obligations (P1)
\end{tabular}

\begin{tabular}{|c|c|c|c|c|c|c|}
\hline \multirow{2}{*}{3} & \multicolumn{6}{|c|}{ Special checks need to be carried out if there are suspected criminal acts } \\
in the field of taxation (P3)
\end{tabular}

a. In the first question (Tax audit needs to be done to test compliance with taxation obligations) as many as 3 respondents (3\%) expressed strongly agree, 31 respondents $(31 \%)$ stated agree 50 respondents $(50 \%)$ stated neutral, 12 respondents $(12 \%)$ stated disagree, then 4 respondents $(4 \%)$ stated strongly disagree.

b. In the second question (Routine inspection needs to be done in the context of supervision of the supervision of corporate taxpayers) as many as 6 respondents (6\%) expressed strongly agree, 21 respondents $(21 \%)$ agreed agree 42 respondents $(42 \%)$ stated neutral, 23 respondents (23\%) stated disagree and then 8 respondents (8\%) stated strongly disagree. 
c. In the third question (Special examination needs to be done if there are alleged criminal acts in the taxation field) as many as 7 respondents (7\%) expressed strongly agree, 41 respondents $(41 \%)$ stated agree 45 respondents (45\%) stated neutral, 5 respondents $(5 \%)$ stated that they disagreed and then 2 respondents $(2 \%)$ stated strongly disagree.

d. In the fourth question (Guidance and counseling needs to be done for taxpayers in question) as many as 13 respondents (13\%) expressed strongly agree, 47 respondents (47\%) agreed, 38 respondents $(38 \%)$ stated neutral, 1 respondent $(1 \%)$ stated that they did not agree, then 1 respondent (1\%) stated strongly disagree

e. On the fifth question (Examination encourages corporate taxpayers to pay and report taxes properly) as many as 10 respondents $(10 \%)$ expressed strongly agree, 28 respondents $(28 \%)$ stated agree 45 respondents $(45 \%)$ stated neutral, 15 respondents $(15 \%)$ stated that they disagreed and then 2 respondents $(2 \%)$ stated strongly disagree.

\begin{tabular}{|l|c|c|c|c|c|c|}
\hline \multirow{2}{*}{1.} & \multicolumn{6}{|c|}{ The sanctions must be implemented strictly for every taxpayer who } \\
commits a violation (P1)
\end{tabular}

To find out the effect corporate taxpayer compliance, the increase of corporate taxpayers' number and tax audits on the income tax receipts of article 25 with taxation sanctions as a moderating variable in KPP Pratama Medan whether or not significant can be seen from the results of the SPSS 21 program as follows:

Based on the results of the validity of the questionnaire variable Corporate Taxpayer Compliance Test $\left(\mathrm{X}_{1}\right)$, it was concluded that from the 5 questionnaire items tested, all question items in the questionnaire were declared valid because after the data were processed all question items had a value of $r_{\text {count }}>r_{\text {table }}$. Thus, all statement items will be used for the data collection process in research. The following table will be presented in the results of the calculation of the validity test of corporate taxpayer Compliance (X1).

\begin{tabular}{|c|c|c|c|c|}
\hline Variable & Item & Cronbach's Alpha & Value of $\mathrm{r}_{\text {table }}$ & Information \\
\hline \multirow{4}{*}{$\begin{array}{c}\text { Corporate Taxpayer } \\
\text { Compliance (X1) }\end{array}$} & 1 & 0,237 & 0,194 & Valid \\
\cline { 2 - 5 } & 2 & 0,298 & 0,194 & Valid \\
\cline { 2 - 5 } & 3 & 0,389 & 0,194 & Valid \\
\cline { 2 - 5 } & 4 & 0,322 & 0,194 & Valid \\
\cline { 2 - 5 } & 5 & 0,399 & 0,194 & Valid \\
\hline \multirow{3}{*}{$\begin{array}{c}\text { The Increase of } \\
\text { Corporate Taxpayers' } \\
\text { Number (X2) }\end{array}$} & 1 & 0,329 & 0,194 & Valid \\
\cline { 2 - 5 } & 2 & 0,325 & 0,194 & Valid \\
\cline { 2 - 5 } & 4 & 0,383 & 0,194 & Valid \\
\cline { 2 - 5 } & 5 & 0,361 & 0,194 & Valid \\
\hline \multirow{2}{*}{ Tax Audit (X3) } & 1 & 0,243 & 0,194 & Valid \\
\cline { 2 - 5 } & 2 & 0,289 & 0,194 & Valid \\
\hline
\end{tabular}




\begin{tabular}{|c|c|c|c|c|}
\hline & 3 & 0,408 & 0,194 & Valid \\
\cline { 2 - 5 } & 4 & 0,393 & 0,194 & Valid \\
\cline { 2 - 5 } & 5 & 0,245 & 0,194 & Valid \\
\hline Income Tax receipts of & 1 & 0,417 & 0,194 & Valid \\
\cline { 2 - 5 } Article 25 (Y) & 2 & 0,382 & 0,194 & Valid \\
\hline Taxation Sanctions (Z) & 1 & 0,347 & 0,194 & Valid \\
\hline
\end{tabular}

Based on the reliability test using the Cronbach's Alpha formula from 5 valid questionnaire items, the reliability tax compliance $\left(\mathrm{X}_{1}\right)$ compliance test is produced in the following table:

\begin{tabular}{|c|c|c|c|}
\hline Variable & Item & Cronbach's Alpha & Value of r table \\
\hline \multirow{4}{*}{$\begin{array}{c}\text { Corporate Taxpayer } \\
\text { Compliance (X1) }\end{array}$} & 1 & 0,522 & 0,194 \\
\cline { 2 - 4 } & 2 & 0,509 & 0,194 \\
\cline { 2 - 4 } & 3 & 0,492 & 0,194 \\
\cline { 2 - 4 } & 4 & 0,501 & 0,194 \\
\hline \multirow{3}{*}{$\begin{array}{c}\text { The Increase of } \\
\text { Corporate Taxpayers } \\
\text { Number (X2) }\end{array}$} & 5 & 0,492 & 0,194 \\
\cline { 2 - 4 } & 2 & 0,510 & 0,194 \\
\cline { 2 - 4 } & 4 & 0,501 & 0,194 \\
\cline { 2 - 4 } & 5 & 0,497 & 0,194 \\
\cline { 2 - 4 } & 2 & 0,505 & 0,194 \\
\cline { 2 - 4 } & 3 & 0,521 & 0,194 \\
\cline { 2 - 4 } Tax Audit (X3) & 4 & 0,514 & 0,194 \\
\cline { 2 - 4 } & 5 & 0,521 & 0,194 \\
\hline Income Tax receipts of & 1 & 0,487 & 0,194 \\
\cline { 2 - 4 } Article 25 (Y) & 2 & 0,490 & 0,194 \\
\hline \multirow{2}{*}{ Tax Sanctions (Z) } & 1 & 0,524 & 0,194 \\
\cline { 2 - 4 } & 2 & 0,490 & 0,194 \\
\hline
\end{tabular}

One of the requirements that must be met in a regression analysis is the data and the regression model must be normally distributed. The normality of data can be seen from the Kolmogorov-Smirnov normality test of each research variable. Data were analyzed with the help of the SPSS 21 program.

The basis for decision making is based on significance. If $r_{\text {count }}>r_{\text {table }}$, then the research data of each variable is normally distributed. Full normality test results can be seen in the following table: 
One-Sample Kolmogorov-Smirnov Test

\begin{tabular}{|ll|r|}
\hline & & $\begin{array}{c}\text { Unstandardized } \\
\text { Residual }\end{array}$ \\
\hline N & Mean & 100 \\
Normal Parameters & Stb. &, 0000000 \\
& Deviation & 1,13636134 \\
Most Extreme & Absolute &, 062 \\
Differences & Positive &, 062 \\
Kolmogorov-Smirnov Z & Negative &,- 046 \\
Asymp. Sig. (2-tailed) & &, 617 \\
\end{tabular}

a. Test distribution is Normal.

b. Calculated from data.

It seen from the table in the Kolomogrov-Smirnov Test One-Sample, the asymp.Sig (2-tailed) value is known to be 0.841 . As explained above if $r_{\text {count }}>d r_{\text {table }}$, the research data is normally distributed. Thus it can be concluded that sig $0.841>0.194$, then this data is normally distributed

Normal distribution results can also be seen from the P-Plot graph. If the points spread around the diagonal line and the distribution follows the direction of the diagonal line, then the data is said to be normally distributed as shown below:

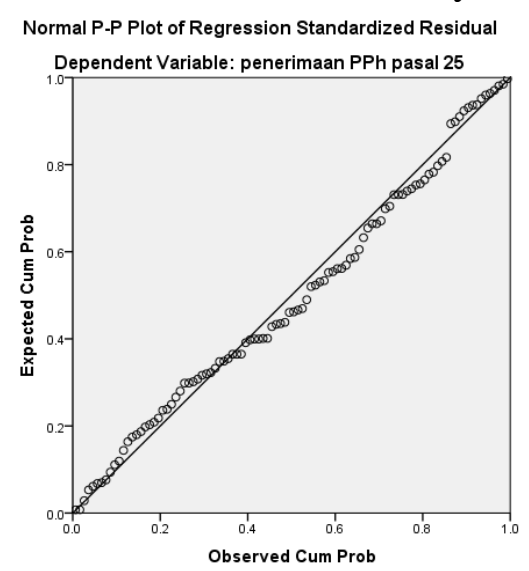

In the picture shows that the point spreads around the diagonal line and follows the diagonal line, it can be concluded that the data obtained are normally distributed.

a. Multicolliniarity Test

Multicollinearity test with SPSS 21 was conducted by researchers using SPSS program assistance, there is no multicollinearity in this study, this can be proved by VIF (Variance Inflation Factor) $<10$. Where of the three Independent variables the VIF value is $<10$. Which states there is no relationship between the variable corporate taxpayer compliance with the growth in the number of corporate taxpayers and tax audits. 


\begin{tabular}{|c|c|c|c|c|c|c|c|}
\hline \multicolumn{8}{|c|}{ Coefficients $^{\mathrm{a}}$} \\
\hline \multirow[t]{2}{*}{ Model } & \multicolumn{2}{|c|}{$\begin{array}{l}\text { Unstandardized } \\
\text { Coefficients }\end{array}$} & $\begin{array}{l}\text { Standardized } \\
\text { Coefficients }\end{array}$ & \multirow[t]{2}{*}{$\mathrm{t}$} & \multirow[t]{2}{*}{ Sig. } & \multicolumn{2}{|c|}{$\begin{array}{l}\text { Collinearity } \\
\text { Statistics }\end{array}$} \\
\hline & $\mathrm{B}$ & Std. Error & Beta & & & Tolerance & VIF \\
\hline Constant) & 13.479 & 2.059 & & 6.548 & .000 & & \\
\hline $\begin{array}{l}\text { Corporate } \\
\text { Taxpayer } \\
\text { Compliance } \\
\text { (X1) }\end{array}$ & .069 & .093 & .078 & .746 & .457 & .925 & 1.081 \\
\hline $\begin{array}{l}\text { The Increase } \\
\text { of Corporate } \\
\text { Taxpayers' } \\
\text { Number (X2 }\end{array}$ & .122 & .083 & 149 & 1.470 & .145 & .977 & 1.024 \\
\hline $\begin{array}{l}\text { Taxation } \\
\text { Audit (X3) }\end{array}$ & .015 & .089 & .017 & .163 & .871 & .911 & 1.098 \\
\hline
\end{tabular}

Dependent Variable: Income Tax receipts of Article 25

\section{c. Heteroscedasticity Test}

Heteroscedasticity test with SPSS 21 is done by researchers using the help of the SPSS program, by observing patterns of interference / residual factors. If the interference factor is randomly spread and does not have a specific pattern, then the model is said to be linear. If the disturbance factor forms a "U" or "U inverse" pattern, then it can be said that the regression equation is not linear. In this research, the model is said to not detect heteroscedasticity because the pattern of factors is spread randomly. The picture can be seen as below:

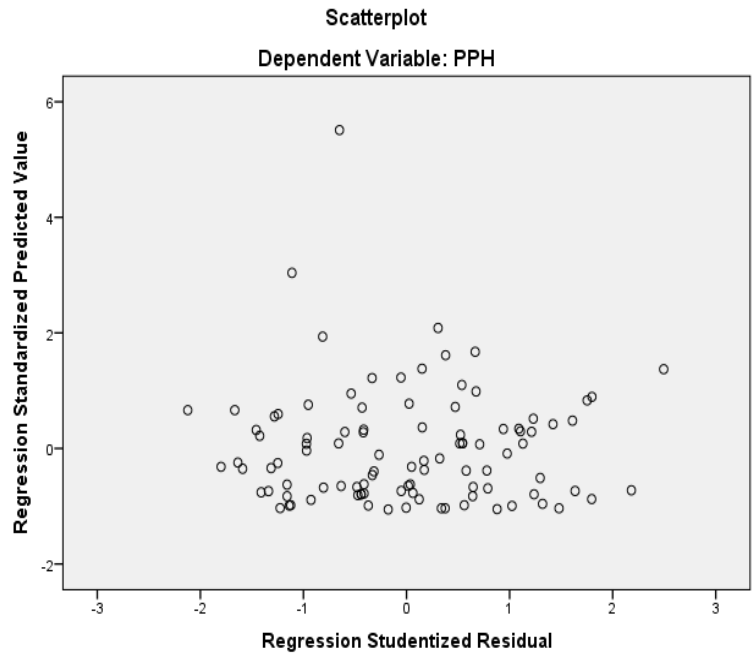

\subsection{Research Data Analysis Results}

a. Multiple Linear Regression Analysis

Multiple linear analysis functions to determine the direction and influence of the variables studied, namely the variables $X_{1}, X_{2}$ and $X_{3}$ on the variable $Y$, whether each variable $X_{1}, X_{2}$ and $X_{3}$ has a positive or negative effect on the $Y$ variable. The results of the 
multiple linear analysis between mandatory compliance variables corporate tax, growth in the number of corporate taxpayers and tax audits can be seen in the table below:

Coefficients $^{\mathrm{a}}$

\begin{tabular}{|c|c|c|c|c|c|}
\hline \multirow[t]{2}{*}{ Model } & \multicolumn{2}{|c|}{$\begin{array}{l}\text { Unstandardized } \\
\text { Coefficients }\end{array}$} & $\begin{array}{l}\text { Standardized } \\
\text { Coefficients } \\
\end{array}$ & \multirow[t]{2}{*}{$\mathrm{t}$} & \multirow[t]{2}{*}{ Sig. } \\
\hline & $\mathrm{B}$ & Std. Error & Beta & & \\
\hline Constant) & 2.175 & 1.287 & & 1.690 & .094 \\
\hline $\begin{array}{c}\text { Corporate Taxpayer Compliance } \\
\text { (X1) }\end{array}$ & .080 & .058 & 137 & 1.373 & .173 \\
\hline $\begin{array}{l}\text { The Increase of Corporate } \\
\text { Taxpayers' Number (X2 }\end{array}$ & .141 & .052 & .263 & 2.701 & .008 \\
\hline Taxation Audit (X3) & .051 & .056 & .091 & .903 & .369 \\
\hline
\end{tabular}

a. Dependent Variable: Income Tax receipts of Article 25

Based on the results of the calculation of multiple linear regression with the help of SPSS 21 in the table above, the multiple regression coefficients obtained for $\mathrm{X}_{1}=0.80, \mathrm{X}_{2}=$ 0.141 and $\mathrm{X}_{3}=0.51$, while the regression constant is 1.451 so that the multiple linear regression equation is:

$$
\mathrm{Y}=\mathrm{a}+\mathrm{b}_{1} \mathrm{X}_{1}+\mathrm{b}_{2} \mathrm{X}_{2}+\mathrm{X}_{3}
$$

$Y=2,175+0,80 X_{1}+0,141 X_{2}+0,51 X_{3}$

\section{b. Simultaneous Test}

If $\mathrm{f}_{\text {count }}<\mathrm{f}_{\text {table }}$ then Ho is accepted, meaning that the effect of corporate taxpayers compliance, the increase of corporate taxpayers' number and tax audits does not significantly effect the Income Tax receipts of Article 25 in KPP Pratama Medan Petisah

If $\mathrm{f}_{\text {count }}<\mathrm{f}_{\text {table }}$ then Ho is rejected, then Ho is accepted, meaning that the effect of corporate taxpayers compliance, the increase of corporate taxpayers' number and tax audits has a significant effect on the Income Tax receipts of Article 25 in KPP Pratama Medan Petisah

\section{ANOVA ${ }^{\mathrm{a}}$}

\begin{tabular}{|c|c|c|c|c|c|}
\hline Model & $\begin{array}{c}\text { Sum of } \\
\text { Squares }\end{array}$ & $\mathrm{df}$ & $\begin{array}{c}\text { Mean } \\
\text { Square }\end{array}$ & $\mathrm{F}$ & Sig. \\
\hline Regression & 16,910 & 3 & 5,637 & 4,233 &, $007^{\mathrm{b}}$ \\
\hline Residual & 127,840 & 96 & 1,332 & & \\
\hline Total & 144,750 & 99 & & & \\
\hline
\end{tabular}

a. Dependent Variable: Income Tax receipts of Article 25

b. Predictors: (Constant), tax audits, growth in the number of corporate taxpayers, corporate taxpayer compliance 


\begin{tabular}{|c|c|c|c|c|c|c|c|c|}
\hline \multicolumn{9}{|c|}{ Coefficients $^{\mathrm{a}}$} \\
\hline \multirow[t]{2}{*}{ Model } & \multicolumn{2}{|c|}{$\begin{array}{l}\text { Unstandardized } \\
\text { Coefficients }\end{array}$} & \multirow{2}{*}{\begin{tabular}{|c|}
$\begin{array}{c}\text { Standardized } \\
\text { Coefficients }\end{array}$ \\
Beta \\
\end{tabular}} & \multirow[t]{2}{*}{$\mathrm{t}$} & \multirow[t]{2}{*}{ Sig. } & \multicolumn{3}{|c|}{ Correlations } \\
\hline & B & Std. Error & & & & Zero-order & Partial & Part \\
\hline Constant) & 2,175 & 1,287 & & 1,690 & ,094 & & & \\
\hline $\begin{array}{l}\text { Corporate Taxpayer } \\
\text { Compliance (X1) }\end{array}$ & ,080 & ,058 & ,137 & 1,373 &, 173 & , 185 & ,139 &, 132 \\
\hline $\begin{array}{l}\text { The Increase of Corporate } \\
\text { Taxpayers' Number (X2 }\end{array}$ & , 141 & 052 & ,263 & 2,701 & 008 & 290 & ,266 & 25 \\
\hline Taxation Audit (X3) & 051 & 056 & ,091 & ,903 & ,369 & , 169 & ,092 & 0 \\
\hline
\end{tabular}

a. Dependent Variable: Income Tax receipts of Article 25

From the data above, the following analysis results are obtained:

a. $\mathrm{T}_{\text {count }}$ results of the effect of corporate taxpayer compliance $(\mathrm{X} 1)$ of 0.137 while $t_{\text {table }}=$ 2.70 , then the $t_{\text {count }}<t_{\text {table }}$. While the significance value of the $t_{\text {count }}$ variable Compliance of corporate taxpayers (X1) of 0.173 means $>0.05$. Based on these results, $\mathrm{H} 0$ is accepted and $\mathrm{Ha}$ is rejected, which means the influence of corporate taxpayer compliance does not have a significant effect on Income Tax receipts of Article 25 (Y).

b. $T_{\text {count }}$ results of the increase of corporate taxpayer's number $(\mathrm{X} 2)$ of 2,701 while $t_{\text {table }}=$ 2.70 , then the value of $t_{\text {count }}>t_{\text {table. }}$. While the significance value of the $t_{\text {count }}$ variable the increase of of corporate taxpayer's number (X2) is 0.008 , meaning $<0.05$. Based on these results, $\mathrm{H} 0$ is rejected and $\mathrm{Ha}$ is accepted, which means the increase of of corporate taxpayer's number has a significant effect on Income Tax receipts of Article 25 (Y).

c. $\mathrm{T}_{\text {count }}$ result of Tax audit (X3) is 0.903 while $\mathrm{t}_{\text {table }}=2.70$, then $\mathrm{t}_{\text {count }}<\mathrm{t}_{\text {table. }}$. While the significance value of the tax audit variable $t_{\text {count }}(\mathrm{X} 2)$ is 0.369 , meaning $>0.05$. Based on these results, $\mathrm{H} 0$ is accepted and $\mathrm{Ha}$ is rejected, which means the tax audit has no significant effect on Income Tax receipts of Article 25 (Y)

Testing the coefficient of determination is done to find out how much the contribution variable corporate taxpayer compliance (X1), the increase of corporate taxpayer's number (X2) and tax audits (X3) of Income Tax receipts of Article 25 (Y) together.

SPSS 21 calculation results, the coefficient of determination is obtained as follows:

Model Summary ${ }^{\mathrm{b}}$

\begin{tabular}{|l|r|r|r|r|}
\hline Model & \multicolumn{1}{|c|}{$\mathrm{R}$} & $\mathrm{R}$ Square & $\begin{array}{c}\text { Adjusted R } \\
\text { Square }\end{array}$ & $\begin{array}{l}\text { Std. Error of } \\
\text { the Estimate }\end{array}$ \\
\hline 1 & .342 & .117 & .089 & 1.154 \\
\hline
\end{tabular}

a. Predictors: (Constant), tax audits, The Increase of

Corporate Taxpayers' Number, corporate taxpayer

compliance

b. Dependent Variable: Income Tax receipts of Article 25 
From the table data above, obtained the coefficient of determination (Adjusted $\mathrm{R}$ square) of 0.117 which means that is $11.7 \%$ variable corporate taxpayer compliance, the increase of corporate taxpayer and tax audits can explain the low against the Income Tax receipts of Article 25. While the rest of $88.7 \%$ is explained by other variables, namely Service Satisfaction Level, modernization of the administration system, understanding tax regulations, which are not examined in this study.

Testing with moderation variables with the Moderated Regression Analysis test aims to see the interaction test moderating variables namely taxation sanctions $(Z)$ can increase or weaken compliance with corporate taxpayers (X1), the increase of corporate taxpayer's number (X2) and tax audits (X3) on Income Tax receipts of Article 25. together.

The Moderating Regression Analysis (MRA) is expressed in the form of an equation as follows:

\section{Coefficients $^{\mathrm{a}}$}

\begin{tabular}{|c|c|c|c|c|c|c|c|}
\hline \multirow[t]{2}{*}{ Model } & \multicolumn{2}{|c|}{$\begin{array}{c}\text { Unstandardized } \\
\text { Coefficients }\end{array}$} & $\begin{array}{c}\text { Standardized } \\
\text { Coefficients }\end{array}$ & \multirow[t]{2}{*}{$\mathrm{t}$} & \multirow[t]{2}{*}{ Sig. } & \multicolumn{2}{|c|}{ Collinearity Statistics } \\
\hline & $\mathrm{B}$ & Std. Error & Beta & & & Tolerance & VIF \\
\hline (Constant) & .936 & .588 & & 1.591 & .115 & & \\
\hline $\begin{array}{l}\text { Z Score: Corporate } \\
\text { Taxpayer Compliance } \\
(\mathrm{ZX} 1)\end{array}$ & .187 & .412 & .009 & .454 & .651 & .923 & 1.083 \\
\hline $\begin{array}{l}\text { Z Score: The increase } \\
1 \text { of Corporate Taxpayer } \\
(\mathrm{ZX} 2)\end{array}$ & .561 & .405 & .026 & 1.386 & .169 & .958 & 1.044 \\
\hline $\begin{array}{l}\text { Zscore: Tax Audit } \\
\text { (ZX3) }\end{array}$ & .009 & .415 & .000 & .021 & .983 & .910 & 1.099 \\
\hline $\begin{array}{l}\text { Zscore: Taxation } \\
\text { Sanctions (Zz) }\end{array}$ & -.046 & .399 & -.002 & -.114 & .909 & .986 & 1.015 \\
\hline ABSX1_X3 & .960 & .019 & .980 & 51.758 & .000 & .969 & 1.032 \\
\hline
\end{tabular}

a. Dependent Variable: PPH

Equation (1): $\mathrm{Y}=\mathrm{a}+\mathrm{b} 1 \mathrm{X} 1+\mathrm{b} 2 \mathrm{X} 2+\mathrm{b} 3 \mathrm{X} 3+\mathrm{b} 4 \mathrm{z}|\mathrm{X} 1 . \mathrm{X} 2 . \mathrm{X} 3-\mathrm{Z}|$

Equation (2): $\mathrm{Y}=0.936+0.561+0.009-0,46)+0.960$

SPSS 21 calculation results, obtained results of Moderated Regression Analysis as follows:

Model Summary ${ }^{b}$

\begin{tabular}{|c|c|c|c|c|c|c|c|c|c|}
\hline \multirow[t]{2}{*}{ Model } & \multirow[t]{2}{*}{$\mathrm{R}$} & \multirow[t]{2}{*}{ R Square } & \multirow{2}{*}{$\begin{array}{c}\text { Adjusted R } \\
\text { Square }\end{array}$} & \multirow{2}{*}{$\begin{array}{l}\text { Std. Error } \\
\text { of the } \\
\text { Estimate }\end{array}$} & \multicolumn{5}{|c|}{ Change Statistics } \\
\hline & & & & & $\begin{array}{l}\text { R Square } \\
\text { Change }\end{array}$ & F Change & $\mathrm{df1}$ & $\mathrm{df} 2$ & $\begin{array}{c}\text { Sig. F } \\
\text { Change }\end{array}$ \\
\hline 1 & $.984^{\mathrm{a}}$ & .967 & .966 & 3.93922 & .967 & 557.116 & 5 & 94 & .000 \\
\hline
\end{tabular}

a. Predictors: (Constant), ABSX1_X3, Zscore: Tax Examination, Zscore: Taxation Sanctions, Zscore:

Increase of Corporate Taxpayers, Zscore: Corporate Taxpayer Compliance

b. Dependent Variable: PPh

\section{Model Summary ${ }^{\mathrm{b}}$}

\begin{tabular}{|l|l|l|l|l|}
\hline Model & R & R Square & Adjusted R Square & Std. Error of the Estimate \\
\hline
\end{tabular}




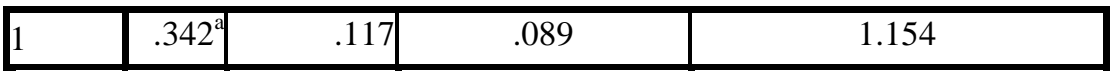

a. Predictors: (Constant), tax audits, the increase of corporate taxpayers' number, corporate taxpayer compliance

b. Dependent Variable: Income Tax receipts of Article 25

\section{Conclusion}

Corporate taxpayer compliance does not have a significant effect on Income Tax receipts of Article 25. The increase of corporate taxpayers' number has a significant effect on Income Tax receipts of Article 25. Tax audits do not have a significant effect on income tax article. Simultaneously corporate taxpayer compliance, the increase of corporate taxpayers' number and tax audits significant effect on income tax receipts of article 25. Taxation sanctions are able to moderate the corporate taxpayer compliance against income tax receipts of article 25. Taxation sanctions are able to increase (moderate) the increase of corporate taxpayers' number on income tax receipts of article 25. Taxation sanctions are able to increase (moderate) tax audits of income tax receipts of article 25. Simultaneously taxation sanctions are able to increase (moderate) corporate taxpayer compliance, the increase of corporate taxpayers' number and tax audits on income tax receipts of article 25.

\section{References}

Cermati. (2016). Pajak Penghasilan: Pengertian dan Cara Menghitungnya, https://www.cermati.com/artikel/pajak-penghasilan-pengertian-dan-caramenghitungnya , accessed on 21 July 2018

Finansialku. (2017). PPh Pasal 25 (Pajak Penghasilan Pasal 25) Tarif, Cara Menghitung, dan Pelaporannya, https://www.finansialku.com/pph-pasal-25-pajak-penghasilan/. accessed on 21 July 2018

Ghozali, I. (2011). Analisis multivarative dengan program aplikasi ibm spss 19. Semarang: Badan penerbit unversitas dipenogoro

Ghozali, I. (2009). Analisis multivarative dengan program spss cetakan ke IV. Semarang: Badan penerbit unversitas dipenogoro

Gunadi. (2013). Panduan Komprehensif Pajak Penghasilan. Jakarta: Bee Media Indonesi

Hatya, D. (2014). pengertian pertumbuhan menurut para ahli. (Online).http://dilihatya.com/2046/pengertian-pertumbuhan-menurut para ahli Ortotax.2007.Tata Cara Penetapan Wajib Pajak Dengan Kritetia Tertentu (Online). http://www.ortax.org/ortax/?mod=aturan\&page=show\&id=13038

Kusumadilaga, R. (2010). Pengaruh social responsibility terhadap nilai perusahaan dengan profitabilitas sebagai variabel moderating. Program sarjana reguler II. Diponegoro University's Faculty of Economics.

Nana. (2011). PPh Pasal 21, 22, 23, 24, 25, dan 26, http://nanapunyblog.blogspot.com/2011/04/pph-pasal-21-22-23-24-25-dan-26.html, accessed on 21 July 2018

Nicho. (2015). Pajak Penghasilan, Apa Itu?, http://nichonotes.blogspot.com/2015/03/PajakPenghasilan.html, accessed on 21 July 2018

Nurmantu, S. (2005). Pengantar Perpajakan. Jakarta: Granit.

Putra, R., D., et al. (2015). Pengaruh pertumbuhan jumlah wajib pajak badan dan kepatuhan wajib pajak badan pasal 25 (studi pada kantor pelayanan pajak pratama yogyakarta 
periode tahun 2010-2012). Jurnal Prodi S1 Akuntansi. Faculty of Economics and Business, Telkom University

Rahayu, S. (2016). Pengaruh Tingkat Kepatuhan Wajib Pajak Badan Dan Pemeriksaan Pajak Terhadap Penerimaan Pph Badan Pasal 25 Pada Kantor Pelayanan Pajak Pratama Surabaya Rungkut. Economic and business faculty accounting study program. Narotama University Surabaya.

Rajab, M. (2017). Pengaruh Profitabilitas Terhadap Nilai Perusahaan Dengan Corporate Social Responsibility Sebagai Variabel Moderating (Studi Empiris Perusahaan Manufaktur Yang Terdapat Di Jakarta Islamic Index Tahun 2011-2015). Faculty of Islamic Economics and Business, North Sumatra State Islamic University.

Rangkuti, I., E., et al. (2017). Perpajakan Indonesia Teori Dan Kasus. Medan: Madenatera Publisher

Ryan. (2010). DJP? Apa Itu?, https://fordispajak.wordpress.com/2010/02/27/djp-apa-itu/ , accessed on 21 July 2018.

Saraswati, A., K. (2012). Analisis Faktor-Faktor Yang Mempengaruhi Kepatuhan Wajib Pajak Badan. Skripsi. Program Sarjana (S1) pada Program Sarjana Fakultas Ekonomi Universitas Diponegoro

Suandy, E. (2005). Hukum Pajak, Edisi 3. Jakarta: Salemba Empat.

Sugiyono. (2012). Metode Penelitian Kuantitatif, Kualitatif, dan R\&D. Bandung: Alfabeta.

Sugiyono. (2014). Metode penelitian kuantitatif, kualitatif, dan kombinasi. Bandung: Alfabeta.

Susanti, E., et al. (2014). Pengaruh wajib pajak badan, kepatuhan wajib pajak badan, dan pemeriksaan pajak terhadap penerimaan Pajak Penghasilan badan pasal 25/29 pada Kantor Pelayanan Pajak Pratama Tampan Pekanbaru. Faculty of economic Riau University. Pekanbaru Indonesia. 